\title{
MINIMUM INHIBITORY AND BACTERICIDAL CONCENTRATIONS OF ANTIBACTERIAL DRUGS SEPARATELY AND TOGETHER WITH METABOLIC COMPLEXES OF LACTOBACILLUS RHAMNOSUS GG AND SACCHAROMYCES BOULARDII
}

\author{
Isayenko O. Yu., Kotsar O. V.
}

\section{INTRODUCTION}

Nowadays the resistance of microorganisms to antibacterial drugs is a global problem of healthcare ${ }^{1}$. Due to the increase in cases of diseases caused by resistant bacteria, the severity of their treatment, frequent mortality, the World Health Organization recommends the development of new antimicrobial agents against multidrug-resistant pathogens ${ }^{2}$. The most dangerous are ESKAPE microorganisms, which are characterized by high antimicrobial resistance. These include the following microorganisms: Enterococcus faecium, Staphylococcus aureus, Klebsiella pneumoniae, Acinetobacter baumannii, Pseudomonas aeruginosa, Enterobacter spp ${ }^{3}$.

It is known that derivatives and metabolic products of microorganisms are successfully used to combat etiologically significant pathogens of diseases separately and together with antibacterial drugs. Scientists have shown that the combined antimicrobial use of nisin (product of metabolism of Streptococcus lactis) with penicillin / chloramphenicol is effective against Staphylococcus aureus SA113 and Staphylococcus pseudintermedius DSM21284. The combination of vancomycin / ciprofloxacin against resistant and methicillin-susceptible strains of $S$. aureus ${ }^{3}$, with polymyxin is effective in inhibiting pseudomonas growth ${ }^{4}$.

${ }^{1}$ Trafton A. Probiotics and antibiotics create a killer combination. Delivered together, the two join forces to eradicate drug-resistant bacteria. MIT News Office. 2018. URL: http://news.mit.edu/2018/probiotics-antibiotics-kill-drug-resistant-bacteria-1017. (дата звернення: 17.10.2018)

${ }^{2}$ Geitani R., Moubareck A.C., Touqui L., Sarkis K.D. Cationic antimicrobial peptides: alternatives and/or adjuvants to antibiotics active against methicillin-resistant Staphylococcus aureus and multidrug-resistant Pseudomonas aeruginos. BMC Microbiology. 2019. Vol. 19, No 1. P. 54-60.

${ }^{3}$ Field D., O'Connor R., Cotter P.D., Ross R.P., Hill C. In vitro activities of nisin and nisin derivatives alone and in combination with antibiotics against Staphylococcus biofilms. Frontiers in Microbiology. 2016. Vol. 7. P. 508-517.

${ }^{4}$ Field D., Seisling N., Cotter P.D., Ross R.P., Hill C. Synergistic nisin-polymyxin combinations for the control of Pseudomonas biofilm formation. Frontiers in Microbiology. 2016. Vol. 7. P. 1713-1719. 
Combinations of actagardine (lantibiotic, produced by Actinoplanes brasiliensis) with ramoplanin / metronidazole / vancomycin showed a partially synergistic / additive effect to Clostridium difficile ${ }^{5}$. Lacticin (lacticin 3147 with Lactococcus lactis) with polymyxin B were effective against S. aureus strain $^{6}$. Plantaricin (product of metabolism of Lactobacillus plantarum) in combination with various antibiotics has been shown to be highly effective against the microorganism Candida albicans ${ }^{7}$. The methicillin-resistant strain of S. aureus ATCC 700699 was highly sensitive to the combination of antimicrobial agents: durancin (durancin 61, produced by Enterococcus durans) with vancomycin ${ }^{8}$. Enterocin CRL35 (producer of Enterococcus mundtii CRL35) with tetracycline / erythromycin / chloramphenicol had a bactericidal effect on Listeria innocua 7 microorganisms ${ }^{9}$.

The widespread use of metabolites of probiotic strains of microorganisms is due to their pronounced antimicrobial properties and a wide spectrum of action. Today, substances of microbial origin, which are used in scientific and research developments to combat antibiotic-resistant microorganisms, as well as lantibiotics, which are in clinical and late preclinical trials, are obtained using traditional nutrient media. These methods include the cultivation of producers on production nutrient media, followed by separation. The cleaning stage is time-consuming, requires additional time, equipment and financial costs. With this in mind, we have developed a new direction for the production of metabolic complexes of probiotic microorganisms with a high level of antimicrobial activity without the use of traditional nutrient media ${ }^{7}$. The advantages of this method are simplicity, accessibility, elimination of an additional purification step, and a reduction in production time. Along with this, the improvement consists in obtaining antimicrobial metabolic complexes with more pronounced properties than in production environments due to the combination of the effectiveness of structural components (disintegrate) and

5 Mathur H., O’Connor R., Cotter P.D., Ross R.P., Hill C. Analysis of antiClostridium difficile activity of thuricin CD, vancomycin, metronidazole, ramoplanin, and actagardine, both singly and in paired combinations. Antimicrobial Agents and Chemotherapy. 2013. Vol. 57. No 6. P. 2882-2886.

${ }^{6}$ Draper L.A., Cotter P.D., Ross R.P., Hill C. The two peptide lantibiotic lacticin 3147 acts synergistically with polymyxin to inhibit gram negative bacteria. BMC Microbiology. 2013. Vol. 13. P. 212-218.

Sharma A., Srivastava S. Anti-candida activity of two-peptide bacteriocins, plantaricins (Pln E/F and J/K) and their mode of action. Fungal Biology. 2014. Vol. 118. No 2. P. 264-275.

${ }^{8}$ Hanchi H., Hammami R., Gingras H., Kourda R., Bergeron M.G., Ben Hamida J., Ouellette M., Fliss I. Inhibition of MRSA and of Clostridium difficile by durancin 61A: synergy with bacteriocins and antibiotics. Future Microbiology. 2017. No 12. P. 205-212.

9 Валышев А.В. Комбинация антибиотиков и бактериоцинов - эффективный способ борьбы с резистентными микроорганизмами. Бюллетень Оренбургского научного центра УрО РАН. 2016. № 4. С. 2-6. URL: http://elmag.uran.ru:9673/ magazine/Numbers/2016-4. 
metabolites $^{10,11}$. Metabolic complexes obtained by cultivating microbial cells of the probiotic strains Lactobacillus rhamnosus GG and Saccharomyces boulardii in their own ultrasonic disintegrates showed pronounced activity against many antibiotic-resistant opportunistic and pathogenic microorganisms. This effectiveness of the combined use of the metabolic complexes of bacteria L. rhamnosus $G G$ and $S$. boulardii, obtained by the author, with antibacterial drugs by serial dilution has not been previously studied. Work on the determination of changes in minimum inhibitory concentrations (MIC) and minimum bactericidal concentrations (MBC) of antibiotics in combination with biologically active substances of lactobacilli and saccharomycetes was not carried out. The aim of this study was to determine the sensitivity of multidrug-resistant strains to antibacterial drugs, both independently and in combination with the metabolic complexes of bacteria $L$. rhamnosus $G G$ and $S$. boulardiifor the possibility of creating on their basis, antibiotic "accompaniments-preparations" and antimicrobial agents with multifunctional activity.

\section{Obtaining biologically active metabolic complexes} of probiotic strains of microorganisms by author's method without the use of traditional nutrient media

\subsection{Obtaining metabolic complexes of Lactobacillus rhamnosus GG and Saccharomyces boulardii by the author's method}

Microbial cells of Lactobacillus rhamnosus GG (with the symbiotic PREEMA ${ }^{\circledR}$, Schonen, Switzerland) and Saccharomyces boulardii (with the probiotic preparation BULARDI®, Schonen, Switzerland) were dissolved in $0,9 \%$ sodium chloride solution, incubated overnight (temperature $37 \pm 1^{\circ} \mathrm{C}$ ). The microbial mass was washed with a $0,9 \%$ sodium chloride solution at least three times (1000 g, 30 minutes).

Disintegrates (structural components) were obtained by irradiation with low-frequency ultrasonic waves (generator G3-109) of a suspensions of L. rhamnosus GG or $S$. boulardii (the concentration of which corresponded to 10,0 units on the McFarland (McF) scale, Densi-La-Meter (PLIVA - Lachema Diagnostika, (Czech Republic)). Processing was carried out in an aqueous medium in a ring device of the generator in the frequency ranges $\Delta \mathrm{f} 2=35 \div 50 \mathrm{kHz}$ (fmax $=40,0 \mathrm{kHz}$ ) with an excitation amplitude of

${ }^{10}$ Спосіб отримання метаболітів пробіотичних штамів бактерій: пат. 123122 Україна. № 2017 08821; заявл. 04.09.17; опубл. 12.02.18, Бюл. № 3.4 c. URL: http://uapatents.com/7-123122-sposib-oderzhannya-metabolitiv-probiotichnikh-shtamivbakterijj.html.

11 Спосіб одержання комбінації метаболітів пробіотичних штамів грибів i бактерій: пат. 126603 Україна. № 2018 01032; заявл. 02.05.18; опубл. 25.06.18, Бюл. № 3.5 c. 
$\mathrm{U}=15 \mathrm{~V}$ at a load of $\mathrm{R}=50 \Omega(\mathrm{P}=5 \mathrm{~W}$.) The coefficient of conversion of electric into acoustic power was $\eta \approx 5 \%$, that is, the average power the acoustic vibrations at the location of biological objects reached $(0,25-0,5) \mathrm{W}$.

Ultrasonic disintegrates of lactobacilli and saccharomycetes were used to cultivate their own microbial cells to obtain metabolic complexes of probiotic origin. Suspensions of L. rhamnosus GG or S. boulardii with an optical density of 10,0 units on the McF scale (seed is $10 \%$ of the total volume) were added to the disintegrates. They were cultured under microaerophilic conditions for three days (temperature $37 \pm 1^{\circ} \mathrm{C}$ ), centrifuged (1000 g, 30 minutes), filtered (Vladipor MFAS-B membrane filters No. 4, pore diameter $0,2 \mu \mathrm{m})^{12}$.

Biologically active substances of probiotic microorganisms obtained by this method are highly active metabolic complexes free of residues of nutrient media. Their pronounced antimicrobial properties are due to the use of proprietary probiotic microorganisms' own ultrasonic disintegrates for cultivation. This allowed to increase the level of antimicrobial activity of the final product due to a combination of the effectiveness of structural components and metabolites of producents ${ }^{13}$.

\subsection{Obtaining a combination of the metabolic complex of Lactobacillus rhamnosus GG and Saccharomyces boulardii by the author's method}

The preparation of microbial suspensions of probiotic strains of lactobacilli and saccharomycetes and the production of disintegrate (structural components) by irradiation with low-frequency ultrasonic waves corresponded to the previous method for producing metabolic complexes. To obtain a combination of metabolites, a mixture of microbial suspensions of $L$. rhamnosus and $S$. boulardii (1: 1), with an optical density of 10,0 units on the McF scale, was introduced into the lactobacillus disintegrate. Seeds accounted for $10 \%$ of the total volume. Then the mixture was cultured under microaerophilic conditions for three days (temperature $37 \pm 1^{\circ} \mathrm{C}$ ), centrifuged (1000 g, 30 minutes), filtered ("Vladipor” MFAS-B membrane filters No. 4, pore diameter $0,2 \mu \mathrm{m}$ ).

A new direction has been proposed for the production of combined biologically active substances of probiotic strains without the use of

12 Спосіб отримання метаболітів пробіотичних штамів бактерій: пат. 123122 Україна. № 2017 08821; заявл. 04.09.17; опубл. 12.02.18, Бюл. № 3.4 c. URL: http://uapatents.com/7-123122-sposib-oderzhannya-metabolitiv-probiotichnikh-shtamivbakterijj.html.

13 Спосібо одержання комбінації метаболітів пробіотичних штамів грибів і бактерій: пат. 126603 Україна. № 2018 01032; заявл. 02.05.18; опубл. 25.06.18, Бюл. № 3.5 c. 
production nutrient media. This method allows the rational use of production resources through a combination of successive stages of obtaining structural components and metabolic products. The advantage also lies in the simplification of the technology of obtaining a combination of metabolites due to the joint cultivation of various types of microorganisms. This eliminates the multi-stage procedures for the separate production of vital products of various probiotic strains, in particular bacteria and fungi, due to the combination of various stages in a single process. The combined biologically active substances of the microorganisms $L$. rhamnosus $G G$ and $S$. boulardii have pronounced antimicrobial properties against many antibiotic-resistant opportunistic and pathogenic microorganisms. The advantage of this combination of the metabolic complex of lactobacilli and saccharomycetes is an increase in antidiphtheria activity compared to individual metabolic complexes ${ }^{14}$.

\section{Determination of the sensitivity of multidrug-resistant bacterial strains to the antibiotic as alone or in combination with a metabolic complex 2.1. Material for determination of MIC and MBC of antibacterial drugs as alone or in combination}

\section{with a metabolic complex against multidrug-resistant pathogens}

Three samples of probiotic origin were selected: the metabolic complex $L$. rhamnosus $G G$, obtained by culturing lactobacilli in their own disintegrate (ML), the metabolic complex $S$. boulardii, obtained by culturing saccharomycetes in their own disintegrate (MS) and a combination of the metabolic complex L. rhamnosus GG and S. boulardii, obtained by culturing co-cultures of lactobacilli and saccharomycetes in lactobacillus disintegrate (MLS). Metabolic complexes in the experiment were used in bacteriostatic concentrations of selected pathogens $0,01-0,14 \mathrm{mg} / \mathrm{ml}$ of total protein determined by the Lowry method ${ }^{15}$.

The following test cultures were used for research: resistant strains of Pseudomonas aeruginosa PR, Enterococcus faecalis PR, Lelliottia amnigena (Enterobacter amnigenus) PR isolated from patients with inflammatory and purulent-inflammatory diseases of the respiratory tract. Antibiotic-resistant cultures of P. aeruginosa PR (to cefoperazone, cefepime, imipenem, meropenem, cefotaxime, ceftriaxone) L. amnigena

14 Ісаєнко О.Ю. Протидифтерійні властивості структурно-метаболітних комплексів пробіотичних штамів лактобактерій і сахароміцетів в тестах in vitro та in vivo. Фізіологічний журнал. 2019. Т. 65, № 6. С. 51-61. doi: 10.15407/fz65.06.051.

${ }^{15}$ Lowry O.H., Rosebrough N.J., Farr A.L., Randall R.J. Protein measurement with the folin phenol reagent. J Biol Chem. 1951. Vol. 193. No 1. P. 265-275. 
(E. amnigenus) PR (to ceftriaxone, cefepime, levofloxacin, ampicillin, doxycycline, amoksiklav), E. faecalis $P R$ (to gentamicin, ceftriaxone, ofloxacin) were taken from the collection of microorganisms of the laboratory for the prevention of respiratory infections, SI «I. Mechnikov Institute of Microbiology and Immunology of National Academy of Medical Sciences of Ukraine». Bacterial suspensions were prepared using 0,9\% sodium chloride solution. The optical density of the samples corresponded to 0,5 units on the McFarland scale (Densi-La-Meter device (PLIVA-Lachema Diagnostika, Czech Republic)).

\subsection{Determination of MIC (inhibitory) antibiotic concentration alone or in combination with a metabolic complex}

The sensitivity of the antibiotic-resistant bacterial strains to the test substances was determined using the serial dilution micromethod in a liquid nutrient medium according to the order ${ }^{16,17}$. The technique was carried out in polystyrene 96-well plates manufactured by EXIMKARGOTREYD LLC (Ukraine). Amikacin (amikacin sulfate, Lekhim-Kharkiv) and ciprofloxacin (Ananta Medicare, Great Britain) were used as antibacterial drugs.

The serial dilution method was based on double serial dilutions of antibiotics: ciprofloxacin (from $64 \mathrm{mg} / \mathrm{ml}$ to $0,03 \mathrm{mg} / \mathrm{ml}$ ) and amikacin (from $1024 \mathrm{mg} / \mathrm{ml}$ to $0,5 \mathrm{mg} / \mathrm{ml}$ ). The experimental samples contained a liquid nutrient medium (Muller-Hinton broth), a bacterial suspension of test cultures and various concentrations of antibacterial drugs individually or in combination with metabolic complexes. Negative control K (-) - nutrient medium with test substances (instead of test cultures, $0,9 \%$ sodium chloride solution was added). Positive control $\mathrm{K}(+)$ - nutrient medium with test cultures (instead of the test substances, $0,9 \%$ sodium chloride solution was added). The optical density of the initial samples was measured (0 hours) after incubation at a temperature of $(37 \pm 1)^{\circ} \mathrm{C}$ after $\sim 22$ hours. To establish the minimum bactericidal concentration (MBC) the contents of the well were inoculated onto a solid nutrient medium (Mueller - Hinton agar).

The MIC (inhibitory) concentration (MIC) of the antibiotic alone or in combination with the metabolic complex was considered the lowest concentration that inhibits the growth of multidrug-resistant strains of

16 The European Committee on Antimicrobial Susceptibility Testing. Breakpoint tables for interpretation of MICs and zone diameters. Version 9.0. 2019. URL: http://www.eucast.org.

${ }^{17}$ Методика визначення та оцінка чутливості мікроорганізмів до антимікробних препаратів (заснована на рекомендаціях EUCAST - Європейського комітету 3 визначення чутливості до антимікробних препаратів: наказ Міністерства охорони здоров'я України. 2017. URL: ukrbio.com.ua > files > Seminar > EUCAST_UKR_ 2017_full_UB. 
microorganisms. The calculation of the results was evaluated visually (complete suppression of visible growth) and spectrophotometrically (the optical density of the samples was measured using an Lisa Scan EM analyzer (Erba Mannheim, Czech Republic) at a wavelength of $630 \mathrm{~nm}$ ). To calculate the degree of inhibition of test cultures by research substances, the formula was used:

$\%$ Inhibition (suppression) $=100-\frac{\mathrm{Od}-\mathrm{On}}{\mathrm{Op}} \times 100$,

where: OD - is the optical density of the experimental sample, On - is the optical density of the negative control, Op - is the optical density of the positive control $^{18}$.

Statistical processing of the results was carried out using Microsoft Office Excel 2007 and Statistica 10.0 (StatSoft Inc., USA). The experimental data are presented as the mean value (x) indicating the standard deviation of the arithmetic mean (SD). Statistical comparison between the individual groups was performed using one-way analysis of variance (ANOVA) corrected by the Bonferroni test. The differences were considered statistically significant when the values were ${ }^{*}-\mathrm{p}<0.05, * *-\mathrm{p}<0.01, * * *-\mathrm{p}<0.001$ relative to the negative control $\mathrm{C}(-)$ and $\S-\mathrm{p}<0.01$, \# $-\mathrm{p}<0.001$ relative to the positive control. The experiment was repeated three times.

\section{The results of minimal inhibitory and bactericidal concentrations of combination of amikacin or ciprofloxacin with metabolic complexes of $L$. rhamnosus $G G$ and $S$. boulardii, obtained by the author's method against multirdrug-resistant microorganisms}

The optical density of samples of microorganisms after incubation in the studied substances was at the initial level and with indicators of negative control, which indicated 100\% inhibition of pathogens (Fig. 1 a, b, c, d, e, f, g). When a combination of ML with ciprofloxacin (C) was added to the medium, the MIC of the latter relative to L. amnigena (E. amnigenus) decreased from $1 \mathrm{mg} / \mathrm{ml}$ to $0,06 \mathrm{mg} / \mathrm{ml}$. The optical density of these samples was 0,07 $\pm 0,005(100 \%$ inhibition) compared with a separate application of the indicated antibiotic concentration - the optical density of which was $0,447 \pm 0,03$ (16,2\% inhibition) (Fig. 1, a). The combination of bacteriostatic concentrations of $\mathrm{C}$ with ML $(0,02 \mathrm{mg} / \mathrm{ml})$ was accompanied by a significantly larger $(\mathrm{p}<0,05)$ decrease in the optical density of the samples $(0,1562 \pm 0,006)$ relative to samples with similar doses of the antibiotic $(0,5147 \pm 0,03)$. The degree of growth inhibition of $L$. amnigena (E. amnigenus) was: under the influence of C + ML - 70,7\%,

18 Sudagidan M., Yemeniciog־lu A. Effects of nisin and lysozyme on growth inhibition and biofilm formation capacity of Staphylococcus aureus strains isolated from raw milk and cheese samples. Journal of Food Protection. 2012. Vol. 75. No 9. P. 1627-1633. 
and $\mathrm{C}-3,5 \%(\mathrm{p}=0,003)$. This can be explained by the fact that the addition of metabolites to antibiotics with a concentration lower than MIC had a more inhibitory effect on the growth of microorganisms.

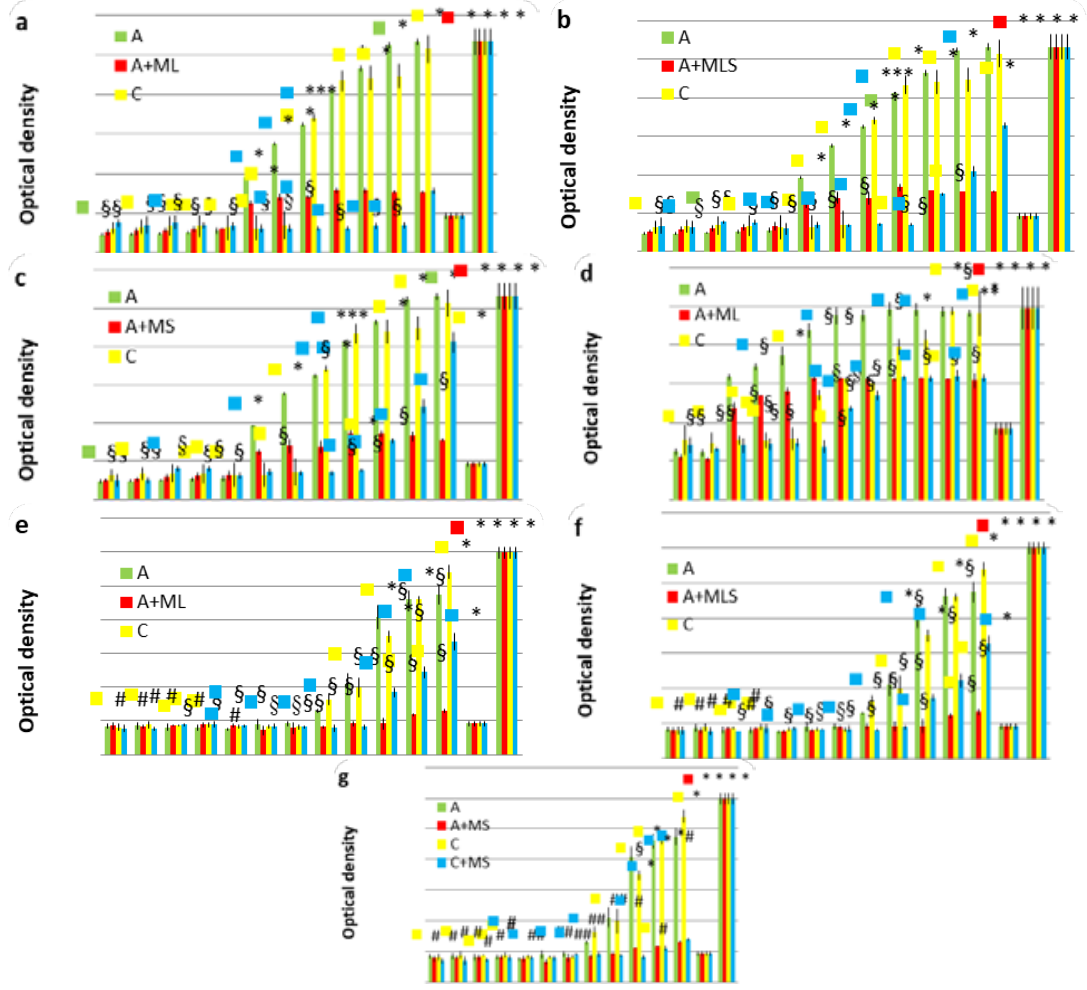

Fig. 1. The MIC value for L. amnigena (E. amnigenus) PR (a, b, c), E. faecalis PR (d), P. aeruginosa PR (e, f, g) combinations of amikacin (A) or ciprofloxacin (C) with metabolic complex of $L$. rhamnosus GG (ML) obtained by culturing lactobacilli in their own disintegrate (a, d, e), a combination of amikacin or ciprofloxacin with the metabolic complex of $L$. rhamnosus GG and $S$. boulardii (MLS), obtained by culturing co-cultures of lactobacilli and saccharomycetes in lactobacillus disintegrate (b, $\mathrm{f}$ ), a combination of amikacin or ciprofloxacin with the metabolic complex of $S$. boulardii (MS) obtained by cultivation saccharomyces in own disintegrate (c, g), negative control C (-) - nutrient medium with the studied filtrates, positive control $\mathrm{C} \mathrm{(+)} \mathrm{-} \mathrm{nutrient} \mathrm{medium}$ with test cultures. The optical density data are presented as the average of the research and control samples $(x \pm S D, n=3)$

Notes: the differences are significant $*-\mathrm{p}<0,05, * *-\mathrm{p}<0,01, * * *-\mathrm{p}<0,001$ relative to the negative control $\mathrm{C}(-)$ and $\S-\mathrm{p}<0,01, \#-\mathrm{p}<0,001$ relative to the positive control $\mathrm{C}(+)$ 
The strain L. amnigena (E. amnigenus) showed less sensitivity to the combined action of ciprofloxacin with MLS and MS: a decrease in the MIC of the antibacterial drug from $1 \mathrm{mg} / \mathrm{ml}$ to $0,25 \mathrm{mg} / \mathrm{ml}(\mathrm{p}<0,05)$ was observed (Fig. 1, b, c). Under the influence of the indicated concentration of ciprofloxacin, growth inhibition of L. amnigena (E. amnigenus) was observed, which amounted to $11,9 \%$ (optical density $0,4343 \pm 0,02$ ) against $100 \%$ inhibition when combined with MS and MLS $(0,01 \mathrm{mg} / \mathrm{ml})$ (optical density $0,07 \pm 0,003(\mathrm{p}=0,001)$ and $0,075 \pm 0,004(\mathrm{p}=0,001)$, accordingly).

A significant inhibition of the multidrug-resistant strain of $P$. aeruginosa was observed with the combined use of MS with ciprofloxacin: the bactericidal concentration decreased from $1 \mathrm{mg} / \mathrm{ml}$ to $0,12 \mathrm{mg} / \mathrm{ml}$ (p <0,0002) (Fig. 1, g). At the indicated antibiotic concentration, inhibition of pseudomonas growth was accompanied by a decrease in the optical density of $0,3498 \pm 0,01$, and when the antibiotic and MS were combined, it was $0,08 \pm 0,006$ (complete elimination of the pathogen). The MIC of ciprofloxacin to $P$. aeruginosa decreased equally (from $1 \mathrm{mg} / \mathrm{ml}$ to $0,25 \mathrm{mg} / \mathrm{ml}, \mathrm{p}<0,02)$ when combined with the metabolite complexes ML $(0,07 \mathrm{mg} / \mathrm{ml})$ or MLS (0,1 mg / ml) (Fig. 1, e, f). The optical densities of combinations of ciprofloxacin with ML $(0,08 \pm 0,006)$ and MLS $(0,08 \pm 0,004)$ corresponded to $100 \%$ inhibition of growth of this pseudomonas strain. The concentration of ciprofloxacin is lower than the MIC reduced the optical density of the samples to $0,3498 \pm 0,01$ (growth inhibition - 58,4\%), and when combined with ML - 0,1851 $\pm 0,01(84,5 \%$ death of microbial cells), with MLS - 0,1733 $\pm 0,009$ (inhibition -86,5\%).

The data presented show that the MIC value of antimicrobial agents can be reduced by using metabolic complexes of lactobacilli and saccharomycetes with respect to multidrug-resistant pathogens. The addition of metabolites to the bacteriostatic concentration of antibiotics has a high inhibitory effect on the growth and reproduction of microbial cells of the pathogen, and is manifested by a significantly larger decrease in the optical density of test cells compared to the action of a single antibiotic. Therefore, when using low concentration antibiotics with metabolic complexes, the synergistic antimicrobial activity persists.

The minimum inhibitory concentration of ciprofloxacin in relation to the multidrug-resistant strain of $E$. faecalis decreased from $4 \mathrm{mg} / \mathrm{ml}$ to $2 \mathrm{mg} / \mathrm{ml}$ when combined with ML (0,14 mg / ml) (Fig. 1, d). No changes in MIC of amikacin (A) by $E$. faecalis under the influence of ML were noted. However, with the combined use of amikacin with ML, which causes a bacteriostatic effect, there was a significant decrease in the optical density $(0,119 \pm 0,007)$ of enterococcal test cells relative to amikacin $(0,1584 \pm 0,009)$. These indicators indicate $89,1 \%$ and $73,1 \%$ inhibition of pathogen growth, respectively $(\mathrm{p}=0,007)$. 
The use of ML with amikacin had a great influence on the growth and reproduction of $P$. aeruginosa microbial cells: the bactericidal concentration decreased from $16 \mathrm{mg} / \mathrm{ml}$ to $2 \mathrm{mg} / \mathrm{ml}$. The optical density of these samples with a metabolic complex was $0.09 \pm 0.01$, in contrast to the optical density without ML 0,4068 $\pm 0,04(\mathrm{p}=0,002)$ (Fig. 1, e). The combination of ML $(0,07 \mathrm{mg} / \mathrm{ml})$ with amikacin in a concentration below the MIC relative to the pathogen under study caused a greater inhibition of the growth of pseudomonas microbial cells compared to the action of a single antibacterial drug. Thus, the optical density of samples with the highest of these concentrations with the relative to pseudomonas strain $(0,4615 \pm 0,02)$ decreased with the addition of ML $(0,1182 \pm 0,003)$ ( $p=0,0007)$.

Similar antimicrobial activity was observed when amikacin was coadministered with a combination of the MLS metabolic complex against a multidrug-resistant strain of $P$. aeruginosa (Fig. 1, f). Their combined effect reduced the bactericidal concentration of amikacin from $16 \mathrm{mg} / \mathrm{ml}$ to $2 \mathrm{mg} / \mathrm{ml}(\mathrm{p}=0,002)$. It should be noted that the addition of MLS $(0,1 \mathrm{mg} / \mathrm{ml})$ to all tested different concentrations of antibiotic also led to a statistically significantly greater bacteriostatic effect on the selected strain of P. aeruginosa than with a single application of the latter $(\mathrm{p}<0,05)$. These data confirm the results of the combined effects of ML and amikacin. The minimum concentration of amikacin required for complete inhibition of $P$. aeruginosa growth decreased from $16 \mathrm{mg} / \mathrm{ml}$ to $4 \mathrm{mg} / \mathrm{ml}$ $(p=0,02)$ when combined with the metabolic complex of saccharomycetes (Fig. 1, g). The minimum bactericidal concentrations (MBC) of combinations of antibacterial drugs with metabolic complexes for all selected multidrug-resistant strains correspond to their minimum inhibitory concentrations.

\section{Analysis of susceptibility indicators of multidrug-resistant microorganisms to the combined use of antibacterial drugs with metabolic complexes of Lactobacillus rhamnosus GG} and Saccharomyces boulardii, obtained by the author's methods

Dependence was found between the antimicrobial effect in a separate test of antimicrobial agents and their combine use with metabolic complexes. The correlation coefficient between the antibacterial activity of amikacin and their combinations with ML against $P$. aeruginosa is $r=0,7368, p=0,007$. A strong correlation for this microorganism was established between the degree of inhibition of pathogen growth under the influence of amikacin and its combination with MLS $(r=1, p=0,007)$ and MS $(r=0,9496, p=0,007)$. A strict direct correlation for this pathogen was found with a combination of ciprofloxacin with MS $(r=1, p=0,02)$ in comparison with a separate use of 
a production drug. A correlation was determined between the bacteriostatic concentration of ciprofloxacin compared with its combination with MLS $(r=0,968, p=0,002)$ and MS $(r=0,73, p=0,03)$. A strong negative correlation was also observed between the antimicrobial effect of bactericidal concentrations of ciprofloxacin, both separately and in combination with ML for representatives of L. amnigena (E. amnigenus) $(\mathrm{r}=1, \mathrm{p}=0,04)$ and $E$. faecalis $(\mathrm{r}=1, \mathrm{p}=0,002)$. A strong direct correlation between microorganisms L. amnigena (E. amnigenus) $(\mathrm{r}=0,999$, $\mathrm{p}=0,0001)$ and $E$. faecalis $(\mathrm{r}=1, \mathrm{p}=0,002)$ was formed between bacteriostatic concentrations of ciprofloxacin separately and together with ML. This indicates that potentiation of metabolic complexes and antibacterial drugs occur not only with bactericidal concentrations of the last one. With the combined use of metabolic complexes with bacteriostatic concentrations of production drugs, a significantly enhanced antimicrobial effect is observed. This allows us to conclude that the combined use of metabolic complexes with antibiotics, in any case, to a greater extent inhibits antibiotic-resistant pathogens in comparison with the individual action of the antibiotic.

The combination of amikacin and ciprofloxacin with ML / MLS / MSC showed high antimicrobial activity against $P$. aeruginosa. Potentiation of ciprofloxacin with ML / MLS / MS was detected in relation to L. amnigena (E. amnigenus). An increase in the antibacterial effect to E. faecalis was observed with a combination of ciprofloxacin with ML (Table 1). A positive result is any reduction in the MIC of the drug in combination with the active substance (metabolic complex). Diagnostic value is a decrease in the inhibitory dose of the antibiotic $\geq 8$ times $^{19}$.

According to the results of the experiments, it was found that all the studied metabolic complexes showed synergistic activity with amikacin or ciprofloxacin and reduced their MIC by 4-8 times relative to $P$. aeruginosa. Among them, the greatest joint effect was observed when using amikacin with ML and MLS, and ciprofloxacin with MS. The maximum combined antimicrobial activity was observed when testing ciprofloxacin with ML to L. amnigena (E. amnigenus): the concentration of the drug decreased by 16 times. And when it is combined with MLS or MS to the same microorganism, the bactericidal concentration decreased four times. The smallest effect (2 times) was obtained with the simultaneous use of ciprofloxacin with ML in relation to E. faecalis.

${ }^{19}$ EUCAST guidelines for detection of resistance mechanisms and specific resistances of clinical and/or epidemiological importance. EUCAST. Version 2.0. 2017. URL: https://www.eucast.org/fileadmin/src/media/PDFs/EUCAST_files/Resistance_ mechanisms/EUCAST_detection_of_resistance_mechanisms_170711.pdf. 
Changes the MIC of antibacterial drugs when used in combination with metabolic complexes of Lactobacillus rhamnosus GG and Saccharomyces boulardii, obtained by the author's methods for multidrug-resistant microorganisms (method of serial dilutions) $(n=3)$

\begin{tabular}{|c|c|c|c|c|c|c|c|c|c|}
\hline \multirow{4}{*}{$\begin{array}{l}\text { Antibacterial } \\
\text { drugs }\end{array}$} & \multicolumn{9}{|c|}{ Multidrug-resistant microorganisms } \\
\hline & \multicolumn{3}{|c|}{ P. aeruginosa } & \multicolumn{3}{|c|}{$\begin{array}{l}\text { L. amnigena } \\
\text { (E. amnigenus) }\end{array}$} & \multicolumn{3}{|c|}{ E. faecalis } \\
\hline & \multicolumn{9}{|c|}{$\begin{array}{c}\text { metabolic complexes of } L \text {. rhamnosus } G G \\
\text { and } S \text {. boulardii }\end{array}$} \\
\hline & $\xi$ & 常 & $\sum_{i}^{\infty}$ & $\xi$ & $\stackrel{\infty}{\beta}$ & $\sum^{\infty}$ & $\xi$ & $\stackrel{\infty}{\sum}$ & $\sum^{\infty}$ \\
\hline Amikacin & 8 & 8 & 4 & - & - & - & - & - & - \\
\hline Ciprofloxacin & 4 & 4 & 8 & 16 & 4 & 4 & 2 & - & - \\
\hline
\end{tabular}

Note: ML is the metabolic complex of L. rhamnosus GG obtained by cultivation of lactobacilli in its own disintegrates, MLS is the combination of the metabolic complex of saccharomycetes and lactobacilli, obtained by cultivation of joint cultures of lactobacilli and saccharomycetes in the disintegrate of lactobacilli, MS is the metabolic complex of S. boulardii obtained by cultivation of saccharomycetes in its own disintegrates; 2-16 synergistic effect (a decrease in the number of MIC of an antibacterial drug) - there is no synergistic effect (a decrease in MIC of an antibacterial drug was not observed).

Thus, changes in the MIC of antibacterial drugs in combination with the metabolic complexes of $L$. rhamnosus GG and S. boulardii, obtained by culturing producents in the disintegrate of probiotic microorganisms that suppressed the growth of multidrug-resistant test cultures, occurred in relation to different bacteria to varying degrees. Experimental studies of the combined effects of metabolic complexes with antibacterial drugs have shown that the effectiveness of synergistic action depends on the antibiotic and the sensitivity of test cultures to experimental combinations.

\section{Assessment of the sensitivity of multidrug-resistant microorganisms to the combined action of antibacterial drugs with the metabolic complexes Lactobacillus rhamnosus GG and Saccharomyces boulardii obtained by the author's methods}

According to preliminary results, antibacterial drugs with metabolites showed a high level of synergistic activity ${ }^{20}$. Amikacin and ciprofloxacin

${ }^{20}$ O.Y. Isayenko, O.V. Knysh, O.V. Kotsar, T.N. Ryzhkova, G.I. Dyukareva, Simultaneous and sequential influence of metabolite complexes of Lactobacillus rhamnosus and Saccharomyces boulardii and antibiotics against poly-resistant Gram-negative bacteria. Regulatory Mechanisms in Biosystems. 2020. Vol 11. No 1. P. 139-145. DOI: https://doi.org/10.15421/022021/ 
were selected according to two criteria. Firstly, they belong to different groups of antibacterial drugs. These antimicrobial agents have a different mechanism of action on microbial cells of pathogens. Aminoglycosides (amikacin) - block protein synthesis and destroy the cytoplasmic membranes of bacteria, fluoroquinolones (ciprofloxacin) - disrupt DNA synthesis in bacterial cells. Secondly, the selected antibiotics attract attention because they can be used to treat infectious skin diseases ${ }^{21}$. The study allowed us to determine not only the degree of suppression of pathogens depending on the concentration of research combinations, but also to establish the effectiveness of the combined use of metabolite complexes with antibacterial drugs that cause various damage to microbial cells of etiologically significant pathogens. The results showed that the effectiveness of the antimicrobial combined effect does not depend on the mechanism of action of the antibiotic on microbial cells of pathogens. Reducing the therapeutic dose of antibacterial drugs, while not reducing the effectiveness of treatment, is important. Of special actuality is the above with respect to drugs with severe toxicity, in particular aminoglycosides.

The results of the combined use of the metabolic complexes of L. rhamnosus $G G$ and S. boulardii with antibacterial drugs are shown to have a synergistic effect, which was manifested by potentiation (substances enhance the antimicrobial effect of each other) or indifferent effect (the effect of one substance does not depend on the presence of the other) for both antibiotics. The antimicrobial combined effect was accompanied by the following changes. The strain of L. amnigena (E. amnigenus) showed even greater sensitivity to the combined use of an antibacterial drug with the metabolic complex ML (a 16-fold decrease in MIC was noted). The data presented have important scientific and practical value, based on the following. Firstly, some representatives of Enterobacteriaceae, in particular E. aerogenes, have polyresistance to fluoroquinolones, beta-lactams, and other antibiotics. The evidence obtained can solve this problem through the introduction of innovative therapeutic approaches to combat antibioticresistant pathogens. Secondly, due to a metagenomic analysis of pathological material obtained from patients with purulent wounds, an overwhelming amount of DNA was found representatives of the family Clostridiaceae and Enterobactericeae. It was difficult to isolate these pathogens during bacteriological studies (S. aureus was isolated

${ }^{21}$ Галимзянов Ф.В. Лечение инфицированных ран и раневой инфекции : учебное пособие. Екатеринбург: УГМА, 2012.88 c. URL: https://docplayer.ru/ 30252647-Lechenie-inficirovannyh-ran-i-ranevoy-infekcii.html. 
predominantly) ${ }^{22,23}$. These results prove the potential for constructing based on metabolic complexes of lactobacilli and saccharomycetes of "accompaniments-preparations" to antibiotics for the treatment of wound infections ${ }^{24,25,26}$. Resistant to ciprofloxacin E. faecalis showed moderate resistance to the combined use of the antibiotic with the metabolite complex ML, despite a decrease in MIC by only half.

\section{CONCLUSIONS}

The results of combined using of metabolites L. rhamnosusGG and $S$. boulardii with antibiotics show synergetic activity which manifested potential and indifferent actions. Metabolic complexes demonstrate a potentiation with antibiotics with different mechanism of action. An intensity of changes depends from concentration of antibacterial drugs and individual sensitivity of test-strains. An increased antimicrobial activity was observed for four combinations ML with such antibiotics (against $P$. aeruginosa - amikacin or ciprofloxacin, against $L$. amnigena (E. amnigenus) and E. faecalis - ciprofloxacin); with MLS and MS - for three combinations (against $P$. aeruginosa - amikacin or ciprofloxacin, against L. amnigena (E. amnigenus) - ciprofloxacin). Expressed potentiation was established by using of combination ML or MLS with amikacin and MS with ciprofloxacin against $P$. aeruginosa. MIC of these antibiotics decreased by 8 times. The largest decrease of MIC (by 16 times) was received by

${ }^{22}$ Щуплова Е.А., Фадеев С.Б. Изучение видового состава микрофлоры очагов гнойно-воспалительных процессов с использованием разных методических подходов. Бюллетень Оренбургского научного центра УрО РАН. 2016. № 2. URL: https://cyberleninka.ru/article/n/izuchenie-vidovogo-sostava-mikroflory-ochagov-gnoynovospalitelnyh-protsessov-s-ispolzovaniem-raznyh-metodicheskih-podhodov.

${ }_{23}$ Тец Г.В., Тец В.В., Ворошилова Т.М., Смирнова Е.И., Кардава К.М., Карамян Т.А., Заславская Н.В., Викина Д.С., Зайцева М.А., Артеменко К.Л., Вечерковская М.Ф. Кауфман А.С. Выбор антибиотика в микробиологическом исследовании гнойно-воспалительных процессов. Клиническая лабораторная диагностика. 2017. T. 62, № 6. C. 372-375. doi: htpp://dx.doi.org/10.18821/0869-2084-2017-62-6-372-375.

Isayenko O.Y., Knysh, O.V., Kotsar, O.V. Ryzhkova T.N. Dyukareva, G.I. Simultaneous and sequential influence of metabolite complexes of Lactobacillus rhamnosus and Saccharomyces boulardii and antibiotics against poly-resistant Gramnegative bacteria. Regulatory Mechanisms in Biosystems. 2020. Vol 11. No 1. P. 139-145. doi: https://doi.org/10.15421/022021.

${ }^{25}$ Isayenko, O., Knysh, O., Kotsar, O., Ryzhkova, T., Dyukareva, G. Evaluation of anti-microbial activity of filtrates of Lactobacillus rhamnosus and Saccharomyces boulardii against antibiotic-resistant gram-negative bacteria. Requlatory Mechanisms in Biosystems. 2019. Vol. 10. № 2. P. 245-250. doi: 10.15421/021937.

${ }^{26}$ Isayenko, O.Y., Knysh, O.V., Babych, Y.M., Ryzhkova, T.N., Dyukareva, G.I. Effect of disintegrates and metabolites of Lactobacillus rhamnosus and Saccharomyces boulardii on biofilms of antibiotic resistant conditionally pathogenic and pathogenic bacteria. Requlatory Mechanisms in Biosystems. 2019. Vol 10. № 1. P 3-8. doi: $10.15421 / 021901$. 
combination ML with ciprofloxacin to L. amnigena (E. amnigenus). Due to the proven effective combined antimicrobial activity of the studied substances of lactobacilli and saccharomycetes with antibacterial drugs, it is possible to reduce the therapeutic concentration of the antibiotic, shorten the period of its use, and slow down the likelihood of developing chronic diseases. Thus, the metabolite complexes obtained by the author's methods are promising for development, "accompaniments-preparations" for new generation antimicrobials.

\section{SUMMARY}

Nowadays the resistance of microorganisms to antibacterial drugs is a global problem healthcare. In this work, the sensitivity of multidrug-resistant strains (Pseudomonas aeruginosa, Enterococcus faecalis, Lelliottia amnigena (Enterobacter amnigenus) was determined, both separately and in combination with the metabolic complexes Lactobacillus rhamnosus GG and Saccharomyces boulardii, obtained by culturing microbial cells in the disintegrate of probiotic microorganisms. The advantages of the new direction of obtaining metabolic complexes with pronounced antimicrobial properties in relation to many antibiotic-resistant opportunistic and pathogenic microorganisms are simplicity, accessibility, elimination of an additional stage of purification from traditional nutrient media, shortened production time, increased antibacterial activity due to the combination of the effectiveness of disintegrates and metabolites. Potentiation of the antibacterial action of the metabolic complexes of L. rhamnosus $G G$ and $S$. boulardii with various mechanisms of antibacterial drugs has been established. The intensity of the changes depends on the concentration of antibacterial drugs and the individual sensitivity of the test culture of the pathogen. Potentiation was established by the combined interaction of metabolic complexes with ciprofloxacin, amikacin. The proof of this fact was the decrease of MIC by 8-16 times. Due to the proven effective combined antimicrobial activity of the metabolites of lactobacilli and saccharomycetes with antibacterial drugs, it is possible to reduce the therapeutic concentration of the antibiotic, shorten the period of its use, and slow down the likelihood of developing chronic diseases. Metabolic complexes are promising "accompaniments-preparations" for the treatment of infectious diseases caused by multidrug-resistant strains.

\section{REFERENCES}

1. Trafton A. Probiotics and antibiotics create a killer combination. Delivered together, the two join forces to eradicate drug-resistant bacteria. MIT News Office. 2018. URL: http://news.mit.edu/2018/probioticsantibiotics-kill-drug-resistant-bacteria-1017. (дата звернення: 17.10.2018). 
2. Geitani R., Moubareck A.C., Touqui L., Sarkis K. D. Cationic antimicrobial peptides: alternatives and/or adjuvants to antibiotics active against methicillin-resistant Staphylococcus aureus and multidrug-resistant Pseudomonas aeruginos. BMC Microbiology. 2019. Vol. 19, No 1. P. 54-60.

3. Field D., O’Connor R., Cotter P. D., Ross R. P., Hill C. In vitro activities of nisin and nisin derivatives alone and in combination with antibiotics against Staphylococcus biofilms. Frontiers in Microbiology. 2016. Vol. 7. P. 508-517.

4. Field D., Seisling N., Cotter P.D., Ross R.P., Hill C. Synergistic nisin-polymyxin combinations for the control of Pseudomonas biofilm formation. Frontiers in Microbiology. 2016. Vol. 7. P. 1713-1719.

5. Mathur H., O’Connor R., Cotter P.D., Ross R.P., Hill C. Analysis of anti-Clostridium difficile activity of thuricin $\mathrm{CD}$, vancomycin, metronidazole, ramoplanin, and actagardine, both singly and in paired combinations. Antimicrobial Agents and Chemotherapy. 2013. Vol. 57. No. 6. P. 2882-2886.

6. Draper L.A., Cotter P.D., Ross R.P., Hill C. The two peptide lantibiotic lacticin 3147 acts synergistically with polymyxin to inhibit gram negative bacteria. BMC Microbiology. 2013. Vol. 13. P. 212-218.

7. Sharma A., Srivastava S. Anti-candida activity of two-peptide bacteriocins, plantaricins (Pln E/F and J/K) and their mode of action. Fungal Biology. 2014. Vol. 118. No 2. P. 264-275.

8. Hanchi H., Hammami R., Gingras H., Kourda R., Bergeron M.G., Ben Hamida J., Ouellette M., Fliss I. Inhibition of MRSA and of Clostridium difficile by durancin 61A: synergy with bacteriocins and antibiotics. Future Microbiology. 2017. No 12. P. 205-212.

9. Валышев А.В. Комбинация антибиотиков и бактериоцинов эффективный способ борьбы с резистентными микроорганизмами. Бюллетень Оренбургского научного цеетра УрО РАН. 2016. № 4. C. 2-6. URL: http://elmag.uran.ru:9673/magazine/Numbers/2016-4.

10. Спосіб отримання метаболітів пробіотичних штамів бактерій: пат. 123122 Україна. № 2017 08821; заявл. 04.09.17; опубл. 12.02.18, Бюл. № 3. 4 c. URL: http://uapatents.com/7-123122-sposib-oderzhannyametabolitiv-probiotichnikh-shtamiv-bakterijj.html.

11. Спосіб одержання комбінації метаболітів пробіотичних штамів грибів і бактерій: пат. 126603 Україна. № 2018 01032; заявл. 02.05.18; опубл. 25.06.18, Бюл. № 3.5 с.

12. Ісаєнко О.Ю. Протидифтерійні властивості структурнометаболітних комплексів пробіотичних штамів лактобактерій i сахароміцетів в тестах in vitro та in vivo. Фізіологічний журнал. 2019. T. 65, No 6. C. 51-61. doi: 10.15407/fz65.06.051. 
13. Lowry O.H., Rosebrough N.J., Farr A.L., Randall R.J. Protein measurement with the folin phenol reagent. J Biol Chem. 1951. Vol. 193. No. 1. P. 265-275.

14. The European Committee on Antimicrobial Susceptibility Testing. Breakpoint tables for interpretation of MICs and zone diameters. Version 9.0. 2019. URL: http://www.eucast.org.

15. Методика визначення та оцінка чутливості мікроорганізмів до антимікробних препаратів (заснована на рекомендаціях EUCAST Європейського комітету 3 визначення чутливості до антимікробних препаратів: наказ Міністерства охорони здоров'я України. 2017. URL: ukrbio.com.ua > files > Seminar > EUCAST_UKR_2017_full_UB.

16. Sudagidan M., Yemeniciog lu A. Effects of nisin and lysozyme on growth inhibition and biofilm formation capacity of Staphylococcus aureus strains isolated from raw milk and cheese samples. Journal of Food Protection. 2012. Vol. 75. No 9. P. 1627-1633.

17.EUCAST guidelines for detection of resistance mechanisms and specific resistances of clinical and/or epidemiological importance. EUCAST. Version 2.0. 2017. URL: https://www.eucast.org/fileadmin/src/media/PDFs/ EUCAST_files/Resistance_mechanisms/EUCAST_detection_of_resistance_ mechanisms_170711.pdf.

18. Isayenko O.Y., Knysh O.V. Kotsar O.V., Ryzhkova T.N. Dyukareva G.I. Simultaneous and sequential influence of metabolite complexes of Lactobacillus rhamnosus and Saccharomyces boulardii and antibiotics against poly-resistant Gram-negative bacteria. Regulatory Mechanisms in Biosystems. 2020. Vol 11. No 1. P. 139-145. doi: https://doi.org/10.15421/022021.

19. Галимзянов Ф.В. Лечение инфицированных ран и раневой инфекции: учебное пособие. Екатеринбург: УГМА, 2012. 88 с. URL: https://docplayer.ru/30252647-Lechenie-inficirovannyh-ran-i-ranevoyinfekcii.html.

20. Щуплова Е.А., Фадеев С.Б. Изучение видового состава микрофлоры очагов гнойно-воспалительных процессов с использованием разных методических подходов. Бюллетень Оренбургского научного иентра УрО РАН. 2016. № 2. URL: https://cyberleninka.ru/article/n/izuchenie-vidovogo-sostava-mikrofloryochagov-gnoyno-vospalitelnyh-protsessov-s-ispolzovaniem-raznyhmetodicheskih-podhodov.

21. Тец Г.В., Тец В.В., Ворошилова Т.М., Смирнова Е.И., Кардава К.М., Карамян Т.А., Заславская Н.В., Викина Д.С., Зайцева М.А., Артеменко К.Л., Вечерковская М.Ф. Кауфман А.С. Выбор антибиотика в микробиологическом исследовании гнойно-воспалительных процессов. Клиническая лабораторная диагностика. 2017. Т. 62, № 6. C. 372-375. doi: htpp://dx.doi.org/10.18821/0869-2084-2017-62-6-372-375. 
22. Isayenko O., Knysh O., Kotsar O., Ryzhkova T., Dyukareva G. Evaluation of anti-microbial activity of filtrates of Lactobacillus rhamnosus and Saccharomyces boulardii against antibiotic-resistant gram-negative bacteria. Regulatory Mechanisms in Biosystems. 2019. Vol. 10. № 2. P. 245-250. doi: 10.15421/021937.

23. Isayenko O.Y., Knysh O.V., Babych Y.M., Ryzhkova T.N., Dyukareva, G.I. Effect of disintegrates and metabolites of Lactobacillus rhamnosus and Saccharomyces boulardii on biofilms of antibiotic resistant conditionally pathogenic and pathogenic bacteria. Regulatory Mechanisms in Biosystems. 2019. Vol 10. № 1. P 3-8. doi: 10.15421/021901.

\section{Information about authors:} Isayenko O. Yu., $\mathrm{MD}, \mathrm{PhD}$ in Medicine, Leading Researcher of the Laboratory of Respiratory Infections Prevention SI "Mechnikov Institute of Microbiology and Immunology of National Academy of Medical Sciences of Ukraine" 14/16, Pushkinska str., Kharkiv, 61057, Ukraine

Kotsar O. V., $\mathrm{PhD}$ in Medicine, Associate Professor of the Department of Microbiology, Virology and Immunology D. P. Grineva Kharkiv National Medical University 4, Nauky Ave, Kharkiv, 61022, Ukraine 